\title{
Efektivitas media video KineMaster terhadap hasil belajar matematika siswa secara daring
}

\author{
Sri Wulandari, Indah Fitria Rahma \\ Pendidikan Matematika, Fakultas Keguruan dan Ilmu Pendidikan \\ Universitas Labuhanbatu \\ Purbabangun, Rantauprapat, Sumatera Utara, Indonesia. \\ *wulanswd629@gmail.com
}

Received: 10 Maret 2021; Accepted: o9 Juni 2021; Published: 30 Juni 2021

\begin{abstract}
Abstrak
Penelitian ini bertujuan mengetahui peningkatan hasil belajar siswa dengan menggunakan media video. Penelitian dilakukan dengan Metode penelitian Quasi Experimental Design merupakan penelitian dengan eksperimen, menggunakan pengembangan dari true experimental design melalui "Non Equivalent Control Grup Design”. Subjek dalam penelitian ini merupakan siswa di kelas XII IPA 1 SMA Negeri II Pangkatan berjumlah 34 orang. Metode dan teknik pengumpulan data menggunakan tes dan observasi secara daring melalui WhatsApp Hasil penelitian menunjukkan bahwa media video berbasis KineMaster meningkatkan hasil belajar siswa kelas XII IPA 1 SMA Negeri II Pangkatan lebih tinggi 14,41 poin dari pada siswa yang tidak menggunakan media video.
\end{abstract}

Kata kunci: Media video, Hasil belajar, Pembelajaran daring

\begin{abstract}
This study aims to determine the increase in student learning outcomes using video media. The research was conducted by using the Quasi Experimental Design research method, namely experimental research, using the development of true experimental design through the "Non Equivalent Control Group Design". The subjects in this study were 34 students in class XII IPA 1 SHS (Senior High School) II Pangkatan . Methods and data collection techniques using tests and online observations via WhatsApp. The results showed that KineMaster-based video media improved student learning outcomes of class XII IPA 1 SHS (Senior High School) II Pangkatan 14.41 points higher than students who did not use video media.
\end{abstract}

Keywords: Video media, Learning outcomes, Online learning 


\section{PENDAHULUAN}

Semua negara terkena dampak adanya covid-19, Indonesia salah satu negara yang terdampak virus corona. Dampak adanya pandemi tersebut sangat mempengaruhi semua bidang salah satunya bidang pendidikan, yaitu adanya perubahan sistem pendidikan nasional pada jenjang sekolah tingkat rendah hingga kepada tingkat mahasiswa yang mewajibkan pembelajaran di rumah (home learning) menggunakan daring (Swastika \& Lukita, 2020). Keadaan pandemi mengakibatkan adanya pembaharuan keputusan yang mendalam pada sistem pendidikan di Indonesia. Bapak Menteri Pendidikan dan Kebudayaan RI, Nadiem Anwar Makarim sudah mengeluarkan beberapa kebijakan untuk mengatur kegiatan pembelajaran secara online. Peraturan itu dikeluarkan melalui pengumumunan pada tanggal 24 Maret 2020 ialah mengenai Pelaksanaan Kebijakan Pendidikan dalam Masa Darurat Penyebaran Corona virus Disease (Covid19), yaitu merubah cara belajar mengajar siswa dengan guru adalah kebijakan belajar dari rumah atau daring (Sutrisno, 2020). Belajar secara daring mengakibatkan kebosanan bagi siswa dalam proses belajar. Maka untuk mengatasi kebosanan itu perlu ada pembelajaan yang interaktif dan menyenangkan (Wulandari et al., 2020).

Peranan metode saat proses belajar mengajar lebih berpengaruh sebagaimana proses pembelajaran dapat berlangsung secara teratur, menyenangkan dan bisa menumbuhkan motivasi belajar siswa. Selain merasa bosan karena belajar secara daring siswa juga bosan dengan materi yang terkesan monoton dan sulit dipahami, sehingga terkadang mereka tidak mau mengerjakan tugas yang di berikan guru di karenakan malas membaca materi yang di berikan, bahkan ada siswa yang lebih memilih melihat internet untuk memahami materi tersebut namun banyak juga yang akhirnya tidak tau apa-apa tentang materi tersebut. Yang menjadi masalah saat ini, instansi pendidikan dipadankan oleh keadaan yang membuat para pendidik bisa memahami materi media video jarak jauh, khususnya di masa pandemi Covid-19 ini. Proses pendidikan jarak jauh dijadikan solusi dalam mengurangi kesusahan dalam proses daring dikarenakan peraturan social distancing terkait mengenai lokasi, waktu dan jarak dan biaya yang menyebabkan kendala besar saat ini (Kusuma \& Hamidah, 2020).

Pendidikan adalah bagian dasar dari negara, jadi negara harus mengusahakan segala cara agar dapat menaikkan kualitas pendidikan tersebut. Terdapat pada Pasal 1 ayat (2) UUD 1945 memuat supaya negara mengadakan suatu sistem pendidikan. Berdasarkan UU No. 20 Tahun 2007 Tentang Sistem Pendidikan Nasional disampaikan bahwa: "Pendidikan merupakan tempat yang tersistem yang dapat mewujudkan nuansa belajar dan proses pembelajaran supaya pesertadidik secara memperluas potensi diri agar mempunyai kecerdasan, pemahaman agama yang baik, jati diri, sopan santun, dan kesenian yang penting untuk seluruh aspek kehidupan.

Pendidikan adalah cara yang terencana dalam kegiatan pembelajaran yang tersusun supaya kelak siswa dapat lebih baik lagi di masa depan. Pendidikan awal merupakan hal yang berpengaruh untuk pendidikan jenjang lebih tinggi kelak" (Purwandi, 2017). Metode akan membuat mudah guru untuk membawakan materi pelajaran dengan menjadi menarik dan tidak membosankan. Pada awalnya metode-metode yang sudah ada belum cukup memberikan celah yang baik bagi pengoptimalan proses pembelajaran sehingga terjadi suasana belajar mengajar yang menyenangkan.

Seperti halnya Menurut Dogmen pembelajaran jarak jauh merupakan pembelajaran yang mengharuskan siswa pada cara belajar mandiri (self study). Belajar mandiri dilaksanakan dengan berstruktur dalam menampilkan materi siswa, memberikan pengarahan kepada 
siswa, dan pemantauan untuk kejayaan belajar siswa (Rahmawati, 2016).

Efektivitas pada KBBI berawal kata efektif yang memiliki arti dominasi dan pengaruh, dan efektif adalah keberhasilan yang sangat memuaskan. Maka, sudah jelaskan bahwa efektivitas adalah hubungan anatara visi dan hasil yang memiliki letak kesamaan antara visi yang diharapkan dengan hasil yang di capai (Sutrisno, 2020). Efektivitas pada bahasa inggris yaitu effective yang artinya tepat atau berhasil. Efektivitas dapat di artikan juga sebagai tinggat tercapainya segala tujuan yang ingin di capai. Jadi efektivitas ialah segala sesuatu yang dapat mengukur sejauh mana tingkat keberhasilan dalam setiap tindakan yang dilakukan (Srimaya, 2017).

Sistem pembelajaran yang menyenangkan akan mendukung siswa agar lebih senang belajar dan terus memotivasi rasa ingin tau pada dirinya, sehingga dapat memotivasi diri, aktif dan kreatif serta mengerti kewajiban pada keputusan yang sudah diambil bersama (Yensy, 2020). Selain menyenangkan pembelajaran yang tepat juga membuat siswa lebih aktif dalam bertanya tentang materi yang di berikan, maka sangat di butuhkan pemberian materi dengan cara yang menyenangkan. Terutama bagi siswa menengah atas, mereka lebih menyukai hal-hal yang menarik dan menyenangkan dari pada hal yang monoton dan membosankan. Dikarenakan situasi yang seperti ini harus di temukan pilihan untuk solusi dan cara pembelajaran pembelajaran.

Kendala yang terdapat dalam siswa maupun guru dapat teratasi jadi diperlukan bahan yang bisa menghilangkan kejenuhan belajar secara daring. Media yaitu salah satu bentuk visual yang digunakan para guru dalam penyajiaan materi kepada siswa yang menjadi hasil penentu tercapai atau tidaknya tujuan pembelajaran (Ainun Mardhiah dan Said Ali Akbar, 2018). Pada masa pendemi ini sangatlah penting memikirkan media yang cocok untuk pembelajaran.
Efektivitas media video KineMaster terhadap hasil belajar matematika siswa secara daring

Dikarenakan media pembelajaran itulah siswa terdorong agar mampu mengerti materi yang disajikan, meskipun siswa belajar secara daring. Media tersebut dapat pula diselaraskan oleh kepribadian siswa dan ketanggapan dalam menggunakan media tersebut (Ahmadi, 2017).

Video menjadi salah satu alternatif yang di pakai guru selama paandemi ini di karena media video sangat mudah dipahami dan dapai di mengerti semua siswa. Dalam lembaga pendidikan media adalah alat ukur yang dapat menentukan ketuntasan kegiatan pembelajaran. Di karenakan adanya media pembelajarn secara sengaja bisa menumbuhkan gaya belajar tersendiri terhadap siswa. Dalam KBBI, media adalah sumber (alat) interaksi, penyampaian, atau penghubung. Dapat juga di lihat dari kata asalnya, 'Medius' (bahasa Latin) yang memiliki arti 'tengah', jadi dapat diartikan bahwa media mengarah pada sebuah sumber/bahan yang dapat menyampaikan tujuan (Khaira, 2021). Sembilan puluh persen para guru mendapat inspirasi dalam membuat materi dari Youtube, dan 65\% para guru mencipkan materi nya sendiri atau ada juga para guru yang bekerjasama dengan rekannya dalam pembuatan materi tersebut.

Banyak sumber yang dapat menjadi insprasi membuatan video yaitu media sosial. Para guru khususnya di Sumatera Barat sudah mampu membuat media video pembelajaran sendiri. Camtasia Studio, Macromedia Flash, Sparkoll Videoscribe dan KineMaster merupakan aplikasi yang dapat digunakan dalam menciptakan media video tersebut (Ridha, 2021).

Hasil pengamatan penelitian yang dilakukan di SMA Negeri II Pangkatan terhadap mata pelajaran matematika ini banyak siswa mengalami kendala terhadap materi yang disampaikan oleh guru kelas melalui daring, sehingga siswa mengirim banyak pertanyaan untuk meminta guru kelas menjelaskan kembali dan disertai contoh yang dapat dipahami dan mudah untuk dimengerti. Maka dalam mengatasi ini peneliti mencoba 
memberikan masukan alternatif kepada guru untuk di buatkan video pembelajaran yang dikemas dalam bahasa yang mudah dimengerti, apabila masih sulit memahaminya maka siswa dapat memutar kembali video tersebut secara terusmenerus sampai benar-benar memahaminya. Hal ini juga di benarkan dengan penelitian yang di lakukan, sehingga media yang digunakan untuk memudahkan siswa dalam memahami materi yaitu media video berbasis KineMaster.

Video merupakan teknologi, perekaman, penangkapan penyimpanan dan pengolahan, pemindahan dan penyesuaian gambar, teks dan menyajikan rekaan dalam gerak sengan elektronik (Ismailah, 2020). Pada bahasa latin video berasal dari kata vidi atau visum dapat diartikan "melihat atau mempunyai daya penglihatan". Pada KBBI, video yaitu rekaman gambar aktif atau acara televisi untuk di sampaikan melalui pesawat televisi (KBBI, 2017). Salah satu media elektronik yang mampu menarik perhatian dan dinamis dengan menyatukan teknologi audio dan visual secara bersamaan yaitu media video.

Dalam sistem pengemasan media video juga sangat mudah sehingga bisa dibawa kemana saja karena dapat di simpan pada $V C D$ ataupun $D V D$, serta dapat mencapai pengguna media tersebut saat disajikan. Pada smartphone juga dapat disimpan dengan mudah (Yudianto, 2017). Pada penelitian dari (Batubara \& Ariani, 2016)) terdapat beberapa keunggulan yang dari penggunaan media berbasisi video, di antaranya adalah sebagai berikut.

a. Mampu memjelaskan materi secara lebih terperinci.

b. Memuat teks dan gambar yang akan memperjelas materi yang telah disajikan.

c. Media video tersebut dapat di pakai dan di lihat kembali saat kita ingin memahami materi yang di berikan.
Efektivitas media video KineMaster terhadap hasil belajar matematika siswa secara daring

d. Lebih membantu dalam mejelaskan secara terperinci terutama tentang ranah perilaku atau psikomotorik.

e. Dibandingkan dengan media teks, media video jauh lebih mudah.

f. Penyelesaian suatu materi bisa dengan mudah di pahami dan di mengerti karena di jelaskan secara terperinci.

Penelitian lainya dari (Yudianto, 2017), media video adalah bahan penyampaian materi yang paling efisien dan cocok untuk menyajikan pesan serta akan sangat mendukung penjelasan materi tersebut. Dengan penayangan sebuah video pembelajaran akan terasa lebih menyengkan dan memahi video yang diputarkan bahwa siswa bisa mengulang kembali jika belum mamahami isi materi. Suara, teks, animasi, dan grafik merupakan fitur yang ada di dalam video. Ranah kognitif (kegiatan mental otak), afektif (Sikap), psikomotorik (keterampilan/skill) dan meningkatkan kemampuan dalam diri dapat digapai melalui media video.

Kesimpulan penelitian ini adalah siswa bisa mewujudkan apa yang diinginkan oleh guru di dalam kelas (Maulana, 2017). Matematika merupakan ilmu yang mempunyai objek berupa konsep, fakta dan operasi juga prinsip. Maka objek itu harus dimengerti secara benar oleh siswa, dikarenakan materi tertentu pada matematika dapat menjadi pedoman untuk bisa memahami materi matematika yang lain, bahkan pada pelajaran yang lain seperti fisika, keuangan (Sapta, 2017).

Pemberian materi dengan menggunakan video dapat membuat siswa ingin mengetahui yang disajikan oleh guru dikarenakan dalam pembelajaran matematika yang sulit dijangkau, media video dapat mempermudah siswa memahami materi tersebut (Tarida, 2020). Pada dasarnya di sekolah menengah, matematikan adalah bidang studi yang tidak 
mudah dimengerti pada siswa dikarena mengharuskan siswa memahami konsep serta sistematis dari konsep tersebut. Matematika juga menjadi salah satu pelajaran yang di takuti untuk siswa dan kurang di gemari, dan itu menyebabkan menurunnya pemahaman dan penerapkan dalam mengerjakan soal matematika menjadi berkurang (Baharuddin, 2014).

Menurut Chorida bahwa matematika merupakan suatu bahasa. Matematika, suatu bahasa sangat diperlukan untuk dikomunikasikan baik secara lisan maupun tulisan sehingga informasi yang disampaikan dapat diketahui dengan baik oleh orang lain (Andy Sapta, 2017). Tempat matematika pada sistem pendidikan mempunyai pengaruh besar, di karenakan dengan mempelajari matematika siswa mampu dilatih agar berpikir secara sistematis, dan menyimpulkan dengan tepat serta benar, juga melatih siswa supaya mempunyai kemampuan berpikir logis serta bernalar. Namun banyak siswa beranggapan jika matematika itu adalah materi sulit di pahami dan pelajaran yang menakutkan, serta salah satu pelajaran kurang digemari oleh siswa sehingga berdampak terhadap prestasi belajar siswa (Rahmatia 1, Artati Iriana 2, 2020).

KineMaster adalah aplikasi yang dapat menata berbagai video dengan smartphone atau laptop. Aplikasi tersebut didukung oleh lapisan video yang berlimpah, audio, gambar, teks, dan efek. Video KineMaster bisa pula terus dibagikan pada akun media sosial (Eka Indriani, 2020). Dengan video berbasis KineMaster pembelajaran diyakini dapat menciptakan suasana yang nyaman dan menyenangkan bagi siswa sehingga bisa membuat mereka tertarik pada materi yang di sampaikan. Dengan begitu, video hasil dari KineMaster bisa langsung di upload ke semua media sosial seperti WhatsApp, YouTube, Facebook, Google+, dan lain sebagainya. Sehingga membuat mudah siswa, serta memudahkan bagi para guru, untuk mempresentasikan video materi yang disampaikan ke siswa. Kegiatan belajar
Efektivitas media video KineMaster terhadap hasil belajar matematika siswa secara daring

mengajar jauh akan menyenangkan hingga dapat mempengaruhi peningkatan hasil belajar siswa. (Khaira, 2021).

KineMaster adalah sebuah aplikasi yang bisa digunakan dengan smartphone yang berguna untuk mengedit berbagai video yang menarik. Dengan menghadirkan tampilan yang cukup simpel akan tetapi KineMaster menyimpan banyak fitur. Hal tersebut dapat membantu siswa agar lebih mengerti pembelajaran yang di sajikan para guru (Iryani, 2020). Setelah penerapan media pembelajaran KineMaster terjadi peningkatan motivasi belajar siswa. Dikarenakan KineMaster merupakan salah satu program pengeditan video terhandal yang bisa digunakan pada smartphone (www.KineMaster.com, 2017) (Fajariyah, 2018).

Tahap-tahap pembuatan video berbasis KineMaster diantaranya adalah: membuat materi baru/video pada media browser, silahkan isi audio (recording atau file), pilih efek dan menyunting timeline, dan simpan video, yang terakhir dengan menyimpan video (save video). Saat proses mengedit video harus terlebih dahulu membuat catatan yang akan di buat, sehingga mengedit video dapat lebih mudah dan lebih tersusun. Adapun tahap-tahap dalam proses editing video menurut (Risah, 2020) adalah sebagai berikut: 1) pilih materi yang mudah untuk dipahami sampaikan kepada siswa; 2) catat materi agar lebih terarah dan mudah dalam pengeditan; 3) buatlah video asli dari materi yang ada; 4) sediakan bahan pendukung yang akan dimuat di video; 5) pilih judul yang padat, tepat dan mudah di mengerti; 6) aetelah selesai materi, masuk ke aplikasi silahkan edit video sesuai kebutuhan dan keinginan.

Keuntungan yang didapat pada pembelajaran mengenakan video KineMaster yaitu, siswa lebih mengerti atas materi yang di sajikan. Tingkat kepahaman siswa di ukur melalui hasil proses belajaryang diperoleh melalui analisis dari proses pembelajaran. Hasil belajar adalah 
proses terakhir dari pembelajaran yang terjadi terutama berkat evaluasi guru

Hasil belajar diambil nilai dari tindakan yang di lakukan siswa sesudah di berikan perlakuan. Hasil belajar bisa tercapai jika media serta pemahaman terhadap materi juga benar. Hasil belajar juga sangat menetukan siswa tuntas atau tidak nya dalam pemahami suatu materi yang diberikan (Silvia Novabriani, 2016). Berdasarkan hasil penelitian yang di lakukan (Akhmad Busyaeri, Tamsik Udin, A. Zaenuddin 2016 ) di Kroya Panguragan Cirebon hasil belajar siswa dengan menggunakan video pembelajaran ternyata mencapai 8o,63 hasil tersebut di pengaruhi pada materi yang diberikan pendidik. Hasil tersebut membuktikan tingginya peninggatan hasil belajar siswa menggunakan media video (Busyaeri et al., 2016). Hasil yang sama juga di didapat pada penelitian (Jusmiana et al., 2020) penelitian tersebut menyimpulkan pemakaian media video sebagai bahan penyampaian materi meningkatkan hasil belajar. Pendapat ini didasarkan dengan adanya perbedaan pada nilai rata-rata post-test 80,36 pada kelas eksperimen hasil belajar IPA siswa lebih tinggi dari nilai rata-rata kelas kontrol yaitu 76,18 . Penelitian tersebut didukung pula melalui nilai rata-rata yang diperoleh dengan penilaian sikap selama proses pembelajaran, pada kelas eksperimen nilainya sebesar 84,16 dan pada kelas kontrol nilainya sebesar 78,5 .

Seiring berjalannya pembelajaran banyak siswa yang mengeluh susahnya memahami materi membuat mereka malas untuk membaca materi yang sudah di berikan. Sehingga hasil belajar mereka juga rendah. Jadi penelitian ini bertujuan untuk meningkatkan kembali hasil belajar siswa dalam pembelajaran selama pandemi covid19 ini melalu media pembelajaran video berbasis KineMaster.

\section{METODE PENELITIAN}

Efektivitas media video KineMaster terhadap hasil belajar matematika siswa secara daring

Penelitian ini bertujuan agar memahami seberapa berpengaruh pada hasil belajar siswa selama pandemi covid-19 ini menggunakan media pembelajaran video berbasis KineMaster. Penelitian dilakukan dengan Metode penelitian Quasi Experimental Design merupakan metode dengan eksperimen, menggunakan pemekaran dari true experimental design dengan "Non Equivalent Control Grup Design” (Prof. Dr. Sugiyono, 2015).

Subjek yang digunakan adalah siswa kelas XII IPA 1 SMA Negeri II Pangkatan dengan jumlah 34 orang. Metode dan teknik pengumpulan data menggunakan tes dan observasi secara daring melalui WhatsApp di karena pandemi yang sedang terjadi sehingga tidak memungkinkan untuk melakukan observasi secara langsung, serta tidak adanya sekolah yang melakukan kegiatan belajar mengajar secara langsung, sehingga observasi hanya di lakukan secara daring melalu media WhatsApp.

Pada penelitian ini memakai cara yaitu Quasi Experimental Design dengan pada sampel melakukan Uji coba dengan one group pretest-protes sebagaimana Tabel 1.

Tabel 1. Metode Penelitian

\begin{tabular}{cccc}
\hline Kelompok & $\begin{array}{c}\text { Pre } \\
\text { test }\end{array}$ & perlakuan & $\begin{array}{c}\text { Post } \\
\text { tes }\end{array}$ \\
\hline Eksperimen & $\mathrm{x}_{1}$ & $\mathrm{Y}$ & $\mathrm{x}_{2}$ \\
Kontrol & $\mathrm{x}_{3}$ & & $\mathrm{x}_{4}$ \\
\hline
\end{tabular}

Keterangan:

$\mathrm{x}_{1} \quad$ : Pretest untuk kelas eksperimen

$\mathrm{x}_{2} \quad$ : Posttes untuk kelas eksperimen

$\mathrm{x}_{3} \quad$ : Pretest untuk kelas kontrol

$\mathrm{x}_{4} \quad$ : Posttes untuk kelas kontrol

$\mathrm{y} \quad$ : treatment (pengaplikasian)

Efektivitas penggunaan media pembelajaran video berbasis KineMaster terhadap hasil belajar siswa adalah $\mathrm{O}_{2}-\mathrm{O}_{1}$. Dimana penelitian dilakukan pada kelas XII IPA 1 berjumlah 34 orang dan di bagi menjadi dua kelompok. Kelompok eksperimen sebanyak 17 orang dengan menggunakan media video KineMaster dan kelompok kontrol sebanyak 17 dengan menggunakan media konvensial. 
Penelitian dilakukan dengan memberikan perlakuan di kelas eksperimen berupa materi menggunakan video KineMaster dan diberikan soal pilihan ganda sebanyak 10 soal. Sedangkan pada kelas kontrol di beri materi berupa power point dan diberikan soal yang sama dengan kelas eksperimen. Dan setiap jawaban benar diberi 10 poin dan jawaban salah diberikan o point. Adapun soal yang di berikan adalah sebagai berikut.

1. Sebuah desa menerima bantuan sebanyak 0,15 . Jumlah penduduk desa 1000 orang, maka diperkirakan tidak menerima bantuan adalah
a. 850 orang
b. 140 orang
c. 123 orang
d. 70 orang

2. Pengambilan secara acak sebanyak 260 kali dari seperangkat kartu dan setiap kali pengambilan kartu dikembalikan, frekuensi harapan yang terambil kartu as?
a.18 kali
b.70 kali
c.2okali
d.8okali

3. Tiga uang koin yang sama dilempar bersama-sama sebanyak 40 kali. Frekuensi harapan agar munculnya 2 gambar di sebelah atas adalah ...
a. 10
b. 8
c. 16
d. 7

4. Sebuah dadu di lempar sebanyak 60 kali. Frekuensi harapan munculnya mata dadu faktor dari 6 adalah ...
a. 50 kali
b.11 kali
c. 60 kali
d.40 kali

5. Setelah 900 kali percobaan lempar undi dua buah dadu bersama-sama,frekuensi harapan munculnya mata dadu berjumlah 5 adalah...
a. 300
b. 345
c. 700
d. 100

6. Setelah 36 kali sebuah dadu di lempar, jadi frekuensi harapan munculnya mata dadu bilangan prima sebanyak ...
a. 7 kali
b. 10 kali

Efektivitas media video KineMaster terhadap hasil belajar matematika siswa secara daring
c. 18 kali
d. 33 kali

7. Pelemparan dadu dengan 50 kali percobaan. frekuensi harapan munculnya mata dadu genap sebanyak
‥
a. 40
b. 30
c. 25
d. 44

8. Peluang seorang murid gagal ujian yaitu o,40. maka peluang seorang murid gagal ujian?
a. 2,3
b. 7,2
c. 2,8
d. 0,6

9. Suatu hari sebanyak 0,05 anak datang terlambat kesekolah dari 300 anak. jumlah anak yang terlambat yaitu?
a. 15
b. 50
c. 20
d.72

10. Sebuah kotak berisi 100 kartu yang diberi nomor 2 sampai dengan 101. sebuah kartu diambil secara acak dari kotak tersebut. Berapakah peluang terambil kartu yang merupakan bilangan kuadrat?
a. $9 / 100$
b. $16 / 100$
c. $1 / 100$
d. $22 / 100$

Setelah subjek penelitian diberikan tes, maka hasil tes dikategorikan pada Tabel 2.

Tabel 2. Spesifikasi Nilai Hasil Belajar

\begin{tabular}{cc}
\hline Nilai Hasil Belajar & Kategori \\
\hline$<55$ & Sangat Rendah \\
$55-64$ & Rendah \\
$65-79$ & Sedang \\
$80-89$ & Tinggi \\
$90-100$ & Sangat Tinggi \\
\hline
\end{tabular}

\section{HASIL DAN PEMBAHASAN}

Analisis data dalam penelitian ini membuktikan penggunaan video berbasis KineMaster efektif terhadap hasil belajar siswa selama pandemi covid-19 dengan 10 item tes pilihan ganda secara daring melalui media WhatsApp. Hasil di kelas eksperimen mendapatkan rata-rata dengan nilai 83,52 sedangkan kelas kontrol memperoleh nilai 
rata-rata 69,11. Hal tersebut menunjukkan bahwa pembelajaran menggunakan video berbasis KineMaster efektif terhadap hasil belajar siswa dalam belajar. Nilai rata-rata tersebut di sajikan pada Tabel 3 sebagai berikut.

Tabel 2. Nilai rata-rata hasil belajar matematika siswa

\begin{tabular}{cc}
\hline Kelas & $\begin{array}{c}\text { Nilai Rata-rata Hasil } \\
\text { Belajar }\end{array}$ \\
\hline Eksperimen & 83,52 \\
Kontrol & 69,11 \\
\hline
\end{tabular}

Hal ini juga sesuai dengan penelitian yang dilakukan (Guswiani et al., 2018) yang menyatakan bahwa penggunaan media video efektif kepada hasil belajar siswa. Dalam penelitian ini juga menyarankan pengunaan video dalam pembelajaran dikarena siswa bahkan lebih mengerti dan memahami isi materi dari pada menggunakan cara yang konvensial.

Sejalan dengan hasil, selama pandemi ini proses belajar-mengajar sangat sulit di lakukan selain dari susahnya siswa memahami materi, siswa juga bosan dengan cara mengajar yang visual maka dari itu media pembelajaran video berbasis KineMaster menjadi salah satu alternatif mengusir kebosanan siswa dalam memahami materi. Selain memudahkan siswa memahami materi, media pembelajaran video berbasis KineMaster juga efektif terdahap hasil belajar siswa karena dalam video pembelajaran tersebut terdapat audio dan berbagai gambar yang berhubungan dengan materi, sehingga siswa lebih mudah dalam memahaminya.

Hasil penelitian ini juga menunjukkan beberapa peningkatan pada hasil belajar siswa yang di dapatkan dengan melihat nilat rata-rata siswa, nilai tertinggi dan terendah yang di dapat siswa setelah pemberian materi, serta tingkat ketuntasan siswa setelah pemberian materi video berbasis KineMaster. Semua dilakukan dengan sistem daring melalui media WhatsApp. Dengan begitu penelitian ini hanya bertujuan untuk mengetahui hasil belajar
Efektivitas media video KineMaster terhadap hasil belajar matematika siswa secara daring

dan pemahaman siswa terhadap materi yang di berikan guru. Hasil analisis menunjukkan bahwa hasil belajar pada kelas eksperimen serta kelas kontrol dengan penggunaan media video berbasis KineMaster tepat dalam peningkatan hasil belajar siswa, seperti di terangkan pada Gambar 1.

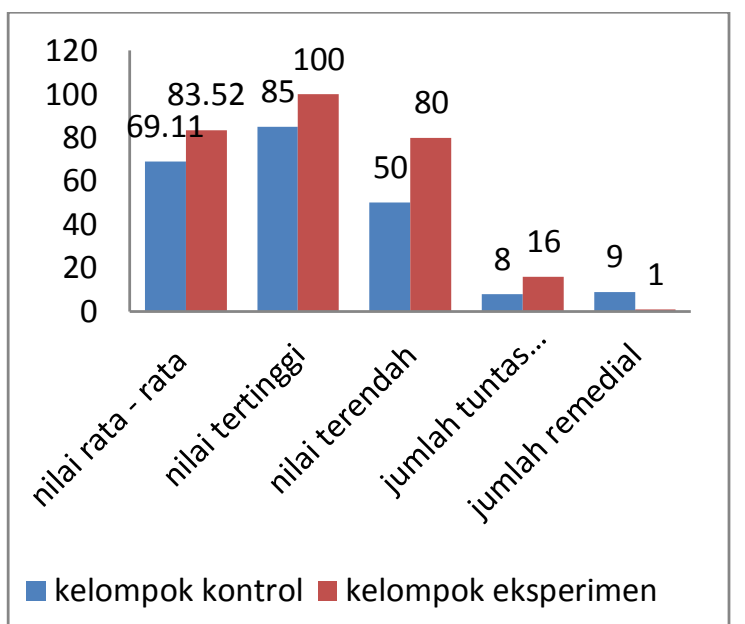

Gambar 1. Peninggakatan hasil belajar siswa pada kelas eksperimen dan kelas kontrol dengan penggunaan media video kine master.

Dari Gambar 1 dijelaskan bahwa terdapat perbandingan yang signifikan dari kelompok eksperimen dan kelompok kontrol, dari nilai rata-rata kelompok eksperimen lebih tinggi 14,41 poin daripada kelas kontrol. Kelompok eksperimen memiliki nilai tertinggi 100 dan terendah 80 sedangkan kelompok kontrol memiliki nilai tertinggi 85 dan terendah 50 . Sehingga jumlah kelompok eksperimen yang tuntas sebanyak 94,11\% dan kelompok kontrol tuntas sebanyak 47,05 \%. Dan kelompok eksperimen dapat mengurangi jumlah siswa yang remedial menjadi 5,89\%. Sehingga hasil penelitian membuktikan bahwa media video berbasis KineMaster efektif terhadap hasil belajar siswa di kelas XII SMA Negeri II Pangkatan. Hal ini sejalan dengan Berdasarkan hasil penelitian yang di lakukan (Akhmad Busyaeri, Tamsik Udin, A. Zaenuddin, 2016 ) di Kroya Panguragan Cirebon Hasil belajar siswa dengan menggunakan video pembelajaran ternyata diperoleh rata-rata hasil belajarnya 
mencapai 8o,63 karena dipengaruhi oleh media yang digunakan guru dalam menyampaikan materi selama proses belajar mengajar. Hal ini membuktikan bahwa tingginya tingkat pengaruh video terhadap hasil belajar siswa (Busyaeri et al., 2016). Begitu juga dengan hasil penelitian yang di lakukan (Guswiani et al., 2018) dan peneliti menyimpulkan dengan Penggunaan video proses belajar menjadi efektif serta peningkatan motivasi dan hasil belajar siswa pada pembelajaran Front Office di Kelas XI Akomodasi Perhotelan SMKN 3 Garut.

Pada penelitian ini sama seperti hasil penelitian (Gusmania \& Dari, 2018) menyatakan jika terdapat perbedaan dampak pada pemakaian media pembelajaran dengan video dan tidak menggunakan media pada pembelajaran konvensional terhadap pemahaman konsep matematis siswa kelas VIII SMPN 20 Batam. Proses belajar menggunakan media video dapat dikatakan berhasil dari pembelajaran tanpa memakai media hal ini didasarkan dari hasil posttest nilai rata-rata kelas eksperimen lebih tinggi dari kelas kontrol.

Berdasarkan hasil dan pembahasan penelitian (Baharuddin, 2014) dapat disimpulkan, hasil belajar matematika siswa kelas XI 3 SMA Negeri 1 Bajo sebelum diberikan media video tutorial berada pada kategori sangat rendah dengan rata-rata 33,75 dari nilai ideal 100. Sedangkan hasil belajar matematika siswa kelas XI 3 SMA Negeri 1 Bajo sesudah diberikan media video tutorial juga berada pada kategori sedang dengan rata-rata 78,25 dari nilai ideal 100 sehingga peningkatan pun terjadi di karena penggunaaan video sebagai media dalam pembelajaran di kelas XI dan di nyatakan efektif serta efesien dalam penggunaannya.

Begitu juga dengan hasil penelitan (Purwandi, 2017) di kelas kontrol dan kelas eksperimen terdapat perbedaan yang besar. Rata-rata nilai pretest dan posttest memberikan peningkatan hasil belajar yang signifikan terjadi dikelas eksperimen, dimana kelas tersebut diberikan perlakuan
Efektivitas media video KineMaster terhadap hasil belajar matematika siswa secara daring

yaitu menggunakan media video dalam penyampaian materinya. Di kelas eksperimen hasil belajar didapatkan melalui angket pretest serta posttest mendapatkan nilai pretest yaitu 7,14 dan posttest yaitu 9,14 dengan nilai rata-rata 8,14 . Sedangkan pada siswa dikelas kontrol yang menggunakan metode ceramah pada penyampaian materi mendapatkan nilai pretest sebesar 7,17 serta nilai posttest hanya sebesar 8,17 dan rata-rata 7,67. Maka dari itu sudah terbukti bahwa penggunaan media video sangat perpengaruh dalam meningkatkan hasil belajar siswa selama pandemi.

Menurut penelitian (Jusmiana et al., 2020) penelitian di SMP Negeri 1 Libureng Kabupaten Bone tersebut menjelaskan adanya dampak yang positif dan signifikan dengan hasil belajar siswa. Didasarkan pada skor rata-rata hasil posttest siswa sebesar $65,60 \%$ atau berada pada kategori rendah pada kelas kontrol, sedangkan skor rata-rata hasil posttest sebesar 75,71\%, atau berada pada katagori sedang siswa pada kelas eksperimen.

Berdasarkan hasil penelitian yang telah dilaksanakan di Universitas Pasir Pengaraia, diperoleh kesimpulan bahwa terdapat dampak yang baik bagi penggunaan video dalam pembelajaran terhadap hasil belajar komputer 1 mahasiswa program studi pendidikan matematika semster II TP. 2019/2020. Pembahasan hasil penelitian ini di kuatkan dengan adanya analisi data pada penelitian tersebut. Hasil analisis data tes komputer I mahasiswa menujukkan bahwa nilai rata-rata komputer I (posttest) kelas eksperimen lebih tinggi dari nilai rata-rata kelas kontrol. Uji hipotesis juga memperlihatkan bahwa ada pengaruh penggunaan video pembelajaran terhadap komputer I (Arcat, 2020).

Dari penelitian yang dilakukan (Khaira, 2021) banyak media serta cara yang diajukan agar di terapkan saat pemberian materi dengan tujuan memudahkan para pengajar memberikan materi yang berkualitas dan 
bermanfaat. Berdasarkan hasil analisis deskriptif yang dilakukan (Rahmatia 1, Artati Iriana 2, 2020) di SMK Negeri 1 Baubau dapat disimpulkan bahwa meningkat dengan prestasi belajar siswa kelas $\mathrm{X}$ dengan penggunaan media pembelajaran video tutorial. Berdasarkan hasil analisis inferensial dapat disimpulkan bahwa penggunaan media pembelajaran video tutorial efektif terhadap prestasi belajar siswa kelas X SMK Negeri 1 Baubau. Sama halnya dengan SMA Negeri II Pangkatan, sistem pembelajaran dilakukan secara daring melalui media WhatsApp dan Google Classroom, sehingga penelitian juga di lakukan dengan proses daring (dalam jaringan). Diantaranya adalah media pembelajaran berbasis ICT dengan memakai aplikasi KineMaster yang bisa menyajikan materi pembelajaran dalam video. Menariknya video pembejalaran tersebut diharapkan bisa membuat para siswa lebih mudah dalam memehami materi secara efektif dan efisien. Maka dari itu penyampaian materi pembelajaran menjadi perhatian dan tidak membosankan serta tertera media audio visual, video, maupun animasi penuh warna (animasi menarik).

Kesimpulan yang diperoleh selama dilakukannya penelitian, proses belajar telah terlaksana dengan baik menggunakan media video dengan KineMaster. Banyak guru yang setuju bahwa pemakaian media video sangat tepat di pakai terutama untuk materi yang memakai kegiatan pratikum. Media video juga salah satu media yang di gemari siswa karena bisa membantu belajar di rumah serta mendorong untuk lebih gemar belajar. Media video juga memotivasi pendidik menemukan atau membuat videovideo yang kreatif dan dapat membantu siswa saat belajar pada masa pandemi Covid19.

Maka hasil penelitian yang di lakukan di SMA Negeri II Pangkatan menyatakan bahwa pembelajaran berbasis video efektif untuk peningkatan hasil belajar serta mampu menghilangkan rasa bosan selama
Efektivitas media video KineMaster terhadap hasil belajar matematika siswa secara daring

belajar daring dan mampu menarik perhatian siswa untuk lebih aktif dalam kegiatan belajar mengajar.

\section{KESIMPULAN}

Penelitian ini mendapatkan kesimpulan bahwa adanya pandemi covid-19 banyak membawa perubahan pada sistem pembelajaran pada pendidikan yang biasanya kegiatan belajar dan mengajar dilakukan tatap muka langsung didalam kelas namun karena adanya wabah tersebut pembelajaran dilakukan secara online atau dapat dikatakan pembelajaran dirumah masing-masing dengan media internet dan smartphone dengan bantuan aplikasi WhatsApp. Kejenuhan dalam pembelajaran membuat siswa lebih sulit memahami materi yang di berikan para guru. Karena keadaan tersebut membuat hasil belajar para siswa menurun dan menjadi rendah sehingga membuat para guru menjadi berfikir keras agar para peseta didik dapat memahami pembelajaran dengan senang dan tidak bosan atas materi yang di berikanj. Sehingga penelitian ini di lakukan bertujuan untuk mengetahui seberapa efektif pembelajaran berbasis video menggunakan KineMaster.

Maka kesimpulan dari penelitian yang telah dilaksanakan di SMA Negeri II Pangkatan, hasil analisis yang didapatkan dari penelitian tersebut yaitu nilai rata-rata kelas eksperimen 83,52 sedangkan kelas kontrol 69,11. Untuk nilai tertinggi, kelas eksperimen mendapatkan nilai 100 dan kelas kontrol nilai 65, untuk nilai terendah kelas eksperimen 80 dan kelas kontrol 50. Dan jumlah siswa yang tuntas pada kelas eksperimen adalah 16 orang dan kelas kontrol 8 orang. Sehingga siswa yang mengalami remedial pada kelas eksperimen hanya 1 orang dan kelas kontrol ada 9 orang.

Hasil penelitian yang dilakukan peneliti antara lain:

1. Penggunaan media belajar video dengan kinemater efektif dalam meningkatkan 
hasil belajar siswa di SMA Negeri II Pangkatan.

2. Media video berbasis KineMaster dapat mengurangi kebosanan siswa dalam belajar dan memudahkan siswa dalam memahani materi matematika yang susah di pahami secara konvensual.

3. Media pembelajaran video berbasis kine master mampu meningkatkan jumlah ketuntasan siswa dalam hasil belajar dan mengurangi jumlah siswa yang remedial.

4. Dengan media video siswa lebih mudah memahami penjelasan yang mungkin sulit untuk di pahami secara visual.

5. Terdapat suara dan gambar/grafik yang lebih spesifik dalam penjelasan materi.

6. Media video KineMaster bisa di gunakan atau di putar kembali secara berulangulang bila siswaa belum memahami materi tersebut.

7. Karena video menggunakan aplikasi KineMaster sehingga memudahkan para gur untuk menyesuaikan materi yang akan di berikan.

8. Banyak gambar dan bentuk tulisan yang menarik pada aplikasi KineMaster yang dapat digunakan untuk lebih menarik perhatian siswa dalam memahami materi.

\section{REFERENSI}

Ainun Mardhiah dan Said Ali Akbar. (2018). Efektivitas media pembelajaran terhadap hasil belajar kimia siswa SMA Negeri 16 Banda Aceh. Lantanida Journal, 6(1), 102.

Arcat. (2020). Pengaruh penggunaan video pembelajaran terhadap hasil belajar
Efektivitas media video KineMaster terhadap hasil belajar matematika siswa secara daring

komputer 1 mahasiswa pendidikan matematika semester II TP. 2019/2020 Universitas Pasir Pengaraian. Jurnal Absis : Jurnal Pendidikan Matematika Dan Matematika, 3(1), 250-256. https://doi.org/10.30606/absis.v3i1.4 96

Baharuddin, I. (2014). Efektivitas penggunaan media video tutorial sebagai pendukung pembelajaran matematika terhadap minat dan hasil belajar siswa SMA Negeri 1 Bajo Kabupaten Luwu Sulawesi Selatan. Jurnal Nalar Pendidikan, 2(2), 247255 .

Batubara, H. H., \& Ariani, D. N. (2016). Pemanfaatan video sebagai media pembelajaran matematika SD/MI. Muallimuna: Jurnal Madrasah Ibtidaiyah, 2(1), 47. https://doi.org/10.31602/muallimuna. v2i1.741

Busyaeri, A., Udin, T., \& Zaenudin, A. (2016). Pengaruh penggunaan video pembelajaran terhadap peningkatan hasil belajar mapel ipa di MIN Kroya Cirebon. Al Ibtida: Jurnal Pendidikan Guru MI, 3(1), 116-137. https://doi.org/10.24235/al.ibtida.snj. v3i1.58

Eka Indriani, Tangson R. Pangaribuan. (2020). Efektivitas penggunaan media KineMaster terhadap kemampuan menulis teks prosedur siswa kelas VII SMP Swasta Muhammadiyah o5 Medan tahun pembelajaran 2019/2020. 154-163.

Fajariyah, L. A. (2018). Pembelajaran Teks Report Dengan Proyek "Cerdig" Berbasis KineMaster. Jurnal Didaktika Pendidikan asar, 2(1), 207-22

Firdaus, F. (2016). Efektivitas Penggunaan Media Audio-Visual Dalam Pembelajaran Sains. SPEKTRA : Jurnal Kajian Pendidikan Sains, 2(01), 46. https://doi.org/10.32699/spektra.v2io 
1.6

Gusmania, Y., \& Dari, T. W. (2018). Efektivitas Penggunaan Media Pembelajaran Berbasis Video Terhadap Pemahaman Konsep Matematis Siswa. PYTHAGORAS: Jurnal Program Studi Pendidikan Matematika, 7(1), 61-67. https://doi.org/10.33373/pythagoras.v 7 i1.1196

Guswiani, W., Darmawan, D., Hamdani, N. A., \& Noordyana, M. A. (2018). EFEKTIVITAS PENGGUNAAN VIDEO PEMBELAJARAN $D A L A M$ PEMBELAJARAN FRONT OFFICE DI KELAS XI AKOMODASI. 3(September), 688-698.

Ilmiani, A. M., Ahmadi, A., Rahman, N. F., \& Rahmah, Y. (2020). Multimedia Interaktif untuk Mengatasi Problematika Pembelajaran Bahasa Arab. Al-Ta'rib: Jurnal Ilmiah Program Studi Pendidikan Bahasa Arab IAIN Palangka Raya. https://doi.org/10.23971/altarib.v8i1.1 902

Iryani, E. (2020). Penggunaan handphone sebagai media pembelajaran melalui aplikasi kine master untuk meningkatkan minat belajar IPS di SMP Negeri 2 Banyuasin III. Keraton: Journal of History Education and Culture.

https://doi.org/10.32585/.v2i2.1159

Jusmiana, A., Herianto, H., \& Awalia, R. (2020). Pengaruh Penggunaan Media Audio Visual Terhadap Hasil Belajar Matematika Siswa Smp Di Era Pandemi Covid-19. Pedagogy: Jurnal Pendidikan Matematika, 5(2), 1-11. https://doi.org/10.30605/pedagogy.v5 i2.400

Ismailah. (2020). Pengembangan Video Pembelajaran Matematika Untuk Kelas Iv Sd. Jurnal Ilmiah Mandala Education, 6(2), 2-7.

Khaira, H. (2021). Pemanfaatan Aplikasi
Efektivitas media video KineMaster terhadap hasil belajar matematika siswa secara daring

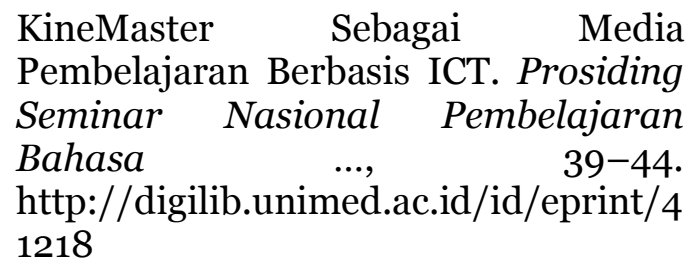

Kusuma, J. W., \& Hamidah, H. (2020). Perbandingan Hasil Belajar Matematika Dengan Penggunaan Platform Whatsapp Group Dan Webinar Zoom Dalam Pembelajaran Jarak Jauh Pada Masa Pandemik Covid 19. JIPMat, 5(1). https://doi.org/10.26877/jipmat.v5i1.5 942

Maulana, M. S. R. (2017). PEMANFAATAN VIDEO SEBAGAI MEDIA PEMBELAJARAN. Ekp, 13(3), 15761580 .

Purwandi, R. (2017). EFEKTIVITAS MEDIA VIDEO UNTUK MENINGKATKAN HASIL BELAJAR MATA PELAJARAN IPS MATERI GEMPABUMI SISWA KELAS VII SMP NEGERI 2 WONOSARI KABUPATEN KLATEN Disusuno Title.

Prof. Dr. Sugiyono. (2015). metode penelitian pendidikan. ALFABETA.

Rahmatia 1, Artati Iriana 2, W. S. 3. (2020). Jurnal akademik pendidikan matematika. Akademik Pendidikan Matematika, 6(November), 62-66.

Rahmawati, I. (2016). Pelatihan dan pengembangan pendidikan jarak jauh berbasis digital class platform edmodo. Prosiding Temu Ilmiah Guru (TING) VII, November, 593-607. https://onesearch.id/Record/IOS4882 .6536

Ridha, M. (2021). Efektifitas Penggunaan Media Video pada Pembelajaran Tematik Terpadu di Sekolah Dasar Saat Pandemi Covid-19. Jurnal Pendidikan Tambusai, 5(1), 154-162. https://jptam.org/index.php/jptam/ar ticle/view/925 
S. Bakhri. (2015). PENGARUH PENGGUNAAN MEDIA VIDEO TERHADAP HASIL BELAJAR IPA SISWA KELAS IV SD NEGERI NGOTO BANTUL YOGYAKARTA TAHUN AJARAN 2014/2015. Skripsi, 151(1), 10-17.Sapta, A. (2017). Pendahuluan. 6(2), 94-99.

Silvia novabriani. (2016). KEEFEKTIFAN MEDIA AUDIO VISUAL TERHADAP MINAT DAN HASIL BELAJAR MATERI STRUKTUR BUMI DAN MATAHARI KELAS V SD NEGERI PESAYANGAN 01 KABUPATEN TEGAL Skripsi. UNNES.Srimaya. (2017). EFEKTIVITAS MEDIA PEMBELAJARAN POWER POINT. Biotek, 5(1), 53-68.

Sutrisno, T. \& A. M. (2020). Vol. 4 No. 2 (2020). PANCAR, 4(2), 53-65.

Swastika, A., \& Lukita, G. (2020). Indonesian Journal of Instructional Motivasi Belajar Dalam Pembelajaran Daring Berbasis Learning Management System ( LMS )
Efektivitas media video KineMaster terhadap hasil belajar matematika siswa secara daring

Schoology Pada Mata Kuliah Probabilitas. 1, 9-13.

Tarida, L. (2020). Pemanfaatan Google Classroom dan Video Pembelajaran berbasis Problem Solving sebagai Solusi Kegiatan Belajar Mengajar di Era Pandemi Covid-19. 5(1).

Wulandari, F., Studi, P., Agama, P., Islam, F. A., Agama, U., \& Surakarta, I. (2020). AUDIO-VISUAL SISWA KELAS VIII PADA MATA PELAJARAN FIQIH DI MASA PANDEMI COVID-19 SEKOLAH MENENGAH PERTAMA MUHAMMADIYAH 7 SURAKARTA TAHUN PELAJARAN 2019/ 2020.

Yensy, N. A. (2020). Efektifitas Pembelajaran Statistika Matematika melalui Media Whatsapp Group Ditinjau dari Hasil Belajar Mahasiswa ( Masa Pandemik Covid 19 ). o5(02), 65-74.

Yudianto, A. (2017). Penerapan Video Sebagai Media Pembelajaran. Seminar Nasional Pendidikan 2017, 234-237. 